\title{
KAJIAN TERHADAP SISWA AKUNTANSI ATAS MOTIVASI BELAJAR, KEPEDULIAN ORANG TUA DAN PRESTASI BELAJAR
}

\section{THE STUDY OF LEARNING MOTIVATION, PARENTS AWARENESS AND LEARNING ACHIEVEMENT OF ACCOUNTING STUDENTS IN BOGOR}

\author{
Y. Triwidatin \\ Program Studi Akuntansi Fakultas Ekonomi Universitas Djuanda Bogor \\ Jl. Tol Ciawi No. 1, Kotak Pos 35, Kode Pos 16720, Telp/Fax : (0251) 8245155 \\ yuppy_triwidati@unida@ac.id
}

\begin{abstract}
The purpose of this study was to determine how much influence learning motivation and parents care about mathematics learning achievement. The Research Method is the Correlational Survey Method. The sample of this study was taken by an affordable population with random proportional techniques, namely as many as 75 students of Amaliah 1 Vocational School and Amaliah 2 Vocational School in Ciawi District, Bogor Regency. The instrument used in this study was in the form of a questionnaire, to measure the variables of learning motivation and caring for parents, as well as in the form of mathematical tests, to measure mathematics learning achievement variables. After testing, the three instruments were declared valid and reliable, so they were suitable for data collection. Furthermore, the data obtained were analyzed descriptively and carried out analysis of the requirements analysis, which included the normality test, multicollinearity test, heteroscedasticity and linearity test, the results of which were normally distributed and linear patterned regression, so the subsequent analysis used correlation coefficient analysis and multiple linear regression.
\end{abstract}

Keywords : Learning Motivation, Parental Concern, Mathematics Learning Achievement

\begin{abstract}
ABSTRAK
Tujuan penelitian ini adalah untuk mengetahui seberapa besar pengaruh motivasi belajar dan kepedulian orang tua terhadap prestasi belajar matematika. Metode Penelitian adalah Metode Survey Korelasional. Sampel penelitian ini diambil populasi terjangkau dengan teknik proporsional acak, yaitu sebanyak 75 siswa SMK Amaliah 1 dan SMK Amaliah 2 Kecamatan Ciawi Kabupaten Bogor. Instrument yang digunakan dalam penelitian ini adalah berbentuk angket, untuk mengukur variabel motivasi belajar dan kepedulian orang tua, serta berbentuk tes matematika, untuk mengukur variabel prestasi belajar matematika. Setelah dilakukan uji coba, ketiga instrument tersebut dinyatakan valid dan reliabel, sehingga layak digunakan untuk pengumpulan data. Selanjutnya data yang diperoleh dianalisis secara deskreptif dan dilakukan uji persyaratan analisis, yang meliputi uji normalitas, uji multikolinearitas, heteroskedastisitas dan uji linieritas yang hasilnya data berdistribusi normal dan regresi berpola linier, sehingga analisis selanjutnya menggunakan analisis koefisien korelasi dan regresi linear berganda.
\end{abstract}

Kata Kunci : Siswa Akuntansi, Motivasi Belajar, Kepedulian Orang Tua, Prestasi Belajar Matematika 


\section{PENDAHULUAN}

Memahami lingkungan-lingkungan pendidikan tidaklah dapat dipisahkan dari konsepsi pendidikan itu sendiri. Makna pendidikan sederhana dapat diartikan sebagai upaya manusia untuk menumbuhkan kepribadiannya sesuai dengan nilai-nilai dalam masyarakat dan budaya. Dengan demikian, betapa pun sederhananya tampilan suatu masyarakat, di dalamnya tentu saja merupakan proses pendidikan. Pendidikan adalah kegiatan yang sadar dengan demikian tujuannya adalah salah satu hal penting dalam kegiatan pendidikan, karena tidak hanya memberikan arah kemana harus pergi, tetapi juga memberikan ketentuan positif dalam memilih materi (konten), metode, alat evaluasi dalam kegiatan yang dilakukan. Secara umum tujuan pendidikan dapat dikatakan. Matematika merupakan salah satu komponen dari serangkaian mata pelajaran yang memiliki peran penting dalam pendidikan. Matematika dapat mendukung pengembangan ilmu pengetahuan dan teknologi. Tidak mengherankan, pelajaran matematika dalam penyelenggaraan pendidikan diberikan kepada semua jenjang pendidikan, mulai dari sekolah dasar hingga perguruan tinggi. Mengingat Prestasi belajar dipengaruhi oleh berbagai faktor. Salah satunya adalah motivasi belajar. pentingnya peran matematika, prestasi belajar matematika setiap sekolah perlu mendapat perhatian serius. Siswa dituntut untuk menguasai pelajaran matematika, karena selain menjadi ilmu dasar juga sebagai sarana berfikir ilmiah yang sangat berpengaruh untuk mendukung keberhasilan belajar siswa dalam menempuh pendidikan tinggi. Prestasi belajar dipengaruhi oleh berbagai faktor. Salah satunya adalah motivasi belajar. Motivasi adalah daya upaya yang mendorong seseorang untuk melakukan sesuatu atau kekuatan pendorong subjek untuk melakukan suatu tindakan dalam suatu tujuan (Sudirman, 2007 : 71). Motivasi sebagai dorongan dasar yang menggerakan seseorang untuk bertingkah laku, hal ini tidak lepas dari adanya rangsangan yang berupa hadiah atau hukuman. Motivasi belajar matematika adalah salah satu kekuatan pendorong yang mengaktifkan siswa untuk melibatkan diri. Motivasi bagi siswa dapat mengembangkan dan mempertahankan ketekunan dalam melakukan kegiatan belajar. Pada anak harus ditanamkan motivasi agar siswa berprestasi harapkan dapat meningkat. Pendidikan merupakan suatu usaha dari setiap bangsa dan negara untuk mewariskan pengetahuan dari generasi ke generasi. Pendidikan tersebut juga diharapkan juga dapat menciptakan peserta didik yang berkualitas dan berbudaya saing persaingan yang tinggi untuk menghadapi era globalisasi saat ini. Meningkatkan kualitas sumber daya manusia adalah salah satu penekanan tujuan pendidikan, sebagaimana tercantum dalam Undang-Undang No. 20 Pada tahun 2003 tentang Bab II Sistem Pendidikan Nasional Pasal 3 yang menyatakan bahwa pendidikan nasional berfungsi untuk mengembangkan kemampuan dalam membentuk karakter dan peradaban bangsa yang bermartabat dalam rangka mencerdaskan bangsa, bertujuan untuk mengembangkan potensi siswa untuk menjadi manusia yang percaya dan takut akan Tuhan, bangsawan, sehat, berpengetahuan, mampu, kreatif, mandiri dan warga negara yang demokratis dan bertanggung jawab.

Dengan adanya undang-undang tersebut maka dari waktu ke waktu bidang pendidikan haruslah tetap menjadi prioritas dan menjadi orientasi untuk ditingkatkan dan dikembangkan agar tujuan pendididkan nasional yang tertuang dalam undang-undang tersebut dapat terwujud. Untuk mewujudkan tujuan pendidikan nasional, pemerintah, keluarga dan masyarakat mempunyai tanggung jawab yang sama.

Lembaga sosial keluarga menurut sejarahnya merupakan lembaga yang pertama dan utama dalam kuasa pengaruhnya terhadap perkembangan anak dan pendidikan. Peranan lembaga ini harus 
ditingkatkan secara terus menerus. Tugas orang tua tidak hanya melahirkan dan membesarkan tetapi lebih dari itu adalah mendidik anak-anak mereka. Tugas ini menjadi semakin berat dan sulit seiring perkembangan dan gejala sosial saat ini. Selain memenuhi kebutuhan yang bersifat materi, tetapi setiap orang tua wajib memenuhi kebutuhan psikologi anakanaknya. Kepedulian orang tua terhadap anak-anaknya dalam pendidikan sangat diperlukan. Walaupun kebutuhan materi tercukupi tetapi jika orang tua kurang mempedulikan belajar anaknya maka prestasi yang dicapai tidak akan maksimal. Oleh karenanya keduanya harus berjalan seimbang. Dari lingkungan belajar tersebut yang paling pertama dikenal anak adalah pendidikan yang berlangsung dalam keluarga yang diberikan oleh orang tuanya dimana anak lahir dan dibesarkan. Menurut Nana Syaodih Sukmadinata (2004: 6) keluarga sering disebut sebagai lingkungan pertama, karena di lingkungan ini anakanak pertama mendapatkan pendidikan, bimbingan, perawatan, pembiasaan dan latihan. Keluarga bukan hanya tempat di mana anak-anak dirawat dan dibesarkan, tetapi juga di mana anak-anak tinggal dan dididik untuk pertama kalinya. Tetapi pada kenyataannya, gejala meningkatnya perhatian orang tua terhadap pendidikan anak-anak belum disertai dengan peningkatan kesadaran orang tua tentang peran mereka sebagai pendidik untuk anakanak dalam keluarga. Ini jelas bahwa hasil pendidikan anak-anak sebagian besar diserahkan kepada pendidikan formal dan non-formal. Pendidikan keluarga adalah hal rutin yang terjadi setiap hari, bahkan setiap saat, karena pada kenyataannya tidak ada istirahat, apalagi libur panjang. Materi apa yang diberikan orang tua kepada anakanak antara orang tua dan orang tua lainnya tidak jauh berbeda, yang terkait dengan aspek spiritualitas, karakter, keterampilan dan pengetahuan dasar yang dapat dikembangkan lebih lanjut di sekolah dan di masyarakat, serta tempat di mana mereka akan bekerja di masa depan. Keluarga adalah salah satu kendaraan yang sangat penting dalam penyelenggaraan pendidikan, orang tua sebagai pendidik sekaligus sebagai penanggung jawab, sudah sepantasnya menyediakan sarana dan prasarana kebutuhan belajar yang diperlukan oleh anak-anaknya. Selain itu orang tua sebagai pendidik dirumah mempunyai pengaruh yang besar terhadap perkembangan anak-anaknya. Orang tua bertanggung jawab untuk mendukung pendidikan anak sehingga tanggung jawab pendidikan bukan hanya terletak pada sekolah saja tetapi menjadi tanggung jawab masyarakat dan lingkungan sekitar utamanya adalah orang tua.

Orang tua bertugas sebagai pengasuh, pembimbing, pemelihara dan sebagai pendidik anak-anaknya. Setiap orang tua pasti menginginkan anak-anaknya menjadi orang yang pandai, cerdas dan berakhlak. Untuk mewujudkan keberhasilan anak yang diinginkan orang tua, faktor orang tua sangat besar pengaruhnya, sebagaimana dikemukakan oleh M. Dalyono (2009 : 59) faktor orang tua sangat besar pengaruhnya terhadap keberhasilan anak dalam belajar. Tinggi Tinggi rendahnya pengetahuan orang tua, besarnya penghasilan orang tua, cukup atau kurang perhatian dan bimbingan orang tua, keharmonisan atau tidak baik orang tua, akrab atau tidaknya hubungan orang tua dengan anak, tenang atau tidaknya situasi di rumah, semua itu juga mempengaruhi pencapaian prestasi belajar anak-anak. Salah satu faktor orang tua yang mempengaruhi keberhasilan belajar anak adalah kepedulian. Kepedulian berarti mengindahkan, menghiraukan atau memperhatikan. Kepedulian orang tua dari anak-anak adalah dasar dari hubungan yang baik di antara anggota keluarga. Perhatian orang tua memiliki pengaruh psikologis yang besar pada kegiatan belajar anakanak. Dengan perhatian orang tua, anak akan lebih aktif dan lebih antusias dalam belajar karena dia tahu bahwa dia tidak sendirian yang ingin maju tetapi juga orang tuanya

Berdasarkan permasalahan diatas peneliti tertarik untuk mengadakan penelitian lebih mendalam mengenai 
pengaruh prestasi belajar matematika dan kepedulian orang tua terhadap prestasi belajar matematika dan kepedulian orang tua terhadap prestasi belajar matematika pada siswa kelas X SMK Swasta di Kecamatan Ciawi Kabupaten Bogor.

\section{Hipotesis Penelitian}

Berdasarkan kajian teori dan kerangka berpikir, maka dapat diajukan hipotesis sebagai berikut :

1. Terdapat pengaruh yang signifikan motivasi belajar dan kepedulian orang tua terhadap prestasi belajar matematika .
2. Terdapat pengaruh yang signifikan antara motivasi belajar terhadap prestasi belajar matematika.

3. Terdapat pengaruh yang signifikan kepedulian orang tua terhadap prestasi belajar matematika.

\section{Metode Penelitian}

Dalam penelitian ini metode penelitian yang digunakan adalah metode survey teknik korelasional dengan analisis regresi. Korelasional masalah digambarkan pada konstelasi masalah pada gambar berikut :



Gambar.1 Konsentrasi Masalah

Keterangan :

$\mathrm{Y}$ : Variabel Terikat : Prestasi belajar

$\mathrm{X}_{1}$ : Variabel bebas 1 : Motivasi

$\mathrm{X}_{2}$ : Variabel bebas 2 : Perhatian orang tua

Konsentrasi tersebut menginformasikan bahwa ada pengaruh simultan variabel motivasi belajar dan kepedulian orang tua secara bersama-sama terhadap prestasi belajar matematika, terdapat pengaruh secara simultan motivasi belajar terhadap prestasi belajar matematika dan ada pengaruh simultan kepedulian orang tua dengan prestasi belajar matematika.

\section{Teknik Analisa data}

1. Analisis Deskriptif

Setelah data terkumpul yang diperoleh melalui instrumen yang dipilih, langkah berikutnya adalah mengolah dan menganalisis data untuk menjawab pertanyaan penelitian, atau menguji hipotesis dengan menggunakan SPSS 16. Statistik deskriptif menggambarkan tentang ringkasan data-data penelitian 
seperti mean, standar deviasi, varian, modus dan lain-lain. dan standar deviasi. Dalam program SPSS ukuran kemiringan dan kurtosis digunakan untuk menggambarkan distribusi data apakah normal atau tidak, selain itu ada beberapa tes untuk mengetahui normalitas data dengan menguji kolmogorov-Smirnov dan Shapiro-Wilk. Dalam pembahasan ini hanya analisis deskriptif yang akan dilakukan dengan memberikan gambaran tentang data, tentang jumlah data, minimum, maksimum, mean

\section{Analisis Persyaratan Data}

Diperlukan sebagai persyaratan melakukan uji hipotesis dengan analisis regresi pada statistik parametrik. Untuk data dari prestasi belajar matematika, motivasi belajar, kepedulian orang tua. Uji persyaratan datanya adalah uji normalitas, uji multikolierritas dan uji heteroskedastisitas.

\section{a. Uji normalitas}

digunakan untuk menngetahui apakah populasi data distribusi normal atau tidak. Tes ini biasanya digunakan untuk mengukur data ordinal, interval atau rasio. Jika analisis menggunakan metode parametrik, maka persyaratan normalitas harus dipenuhi, yaitu data berasal dari distribusi normal. Jika data tidak terdistribusi normal atau jumlah sampel kecil dan tipe data normal atau ordinal, metode yang digunakan adalah statistik non parametrik. Dalam diskusi ini kita akan menggunakan uji One Sample Kolmogorov-Smirnov menggunakan tingkat signifikansi 0,05 , data terdistribusi normal jika signifikansi lebih besar dari 5\% atau 0,05 .

1. Menentukan taraf signifikansi $(\alpha)$ pada penelitian ini menggunakan $\alpha$ $=5 \%$ atau 0,05

2. Penggujian normalitas Sebelum menguji hipotesis, berdasarkan data yang dikumpulkan dari hasil penelitian ini, tes normalitas dilakukan pada data ini. Uji normalitas ini dilakukan menggunakan

SPSS 16 yaitu dengan Kolmogorov Smirnov dengan taraf signifikan $\alpha=$ 0,05 dengan jumlah responden sebanyak 75 orang dengan hipotesis pengujian normalitas sebagai berikut :

$\mathrm{H}_{\mathrm{o}}$ : Data berdistrubsi normal

$\mathrm{H}_{1}$ : Data berdistribusi tidak normal Kriteria pengujian dengan menggunakan nilai probabilitas (Sig)

Terima $\mathrm{H}_{\mathrm{o}}$ : Jika nilai probabilitas $>0,05$ yang berarti data berdistribusi normal

Tolak $\mathrm{H}_{\mathrm{o}} \quad$ : Jika nilai probabilitas $<0,05$ yang berarti data tidak berdistribusi normal

Hipotesis yang diajukan adalah :

Ho: $\sigma_{1}^{2}=\sigma_{2}^{2}=\ldots=\sigma_{\mathrm{n}}^{2}$ (semua populasi mempunyai varians sama homogen)

$\mathrm{H}_{1}: \sigma_{1}^{2} \neq \sigma_{2}^{2} \neq \ldots \neq \sigma_{\mathrm{n}}^{2}$ (ada popolasi yang mempunyai variasi berbeda/tidak homogen).

b. Uji multikolinieritas

digunakan untuk menentukan apakah ada penyimpangan klasik dari asumsi multikolinearitas, yaitu adanya hubungan linear antara variabel independen dalam model regresi. Persyaratan yang harus dipenuhi dalam model regresi adalah tidak adanya multikolinieritas. Dalam diskusi ini tes multikolinieritas akan dilakukan dengan melihat nilai faktor inflasi (VIF) dalam model regresi dan membandingkan nilai koefisien serentak. VIF menurut Santoso (2001) pada umumnya jika VIF lebih besar dari 5 maka variabel tersebut mempunyai persoalan multikolinearitas dengan variabel bebas lainnya.

\section{c. Uji heteroskedastisitas}

bertujuan untuk menguji apakah dalam model regresi terjadi 
ketidaksamaan variance dari residual satu pengamatan ke pengamatan lain. Jika variance dan residual satu pengamatan ke pengamatan lainnya tetap maka disebut homoskedastisitas dan jika berbeda disebut heteroskedastisitas. Kriteria pengujian adalah terjadi heteroskedastisitas apabila gambar scatterplot menunjukan pola tertentu.

\section{d. Uji Linearity}

bertujuan untuk mengetahui apakah dua variabel memiliki hubungan yang linier atau tidak signifikan. Tes ini biasanya digunakan sebagai prasyarat dalam analisis korelasi atau regresi linier dalam SPSS menggunakan Uji Untuk Linearitas dengan tingkat signifikansi 0,05 dua variabel dikatakan memiliki hubungan linier jika signifikansi (Linearitas) kurang dari 0,05 .

\section{e. Uji Homogenitas}

Setelah dilakukan uji normalitas memberikan indikasi bahwa data berdistribusi normal, maka selanjutnya dilakukan uji homogenitas dari sampel penelitian (kelas eksperimen dan kelas kontrol). Uji homogenitas dimaksudkan untuk menguji apakah data berasal dari populasi yang homogen atau tidak. Uji homogenitas data dihitung menggunakan program SPSS versi 16, uji homogenitas tes dilakukan untuk menguji asumsi variance sama atau asumsi variance tidak sama dengan membandingkan Pvalue dan $\alpha=0,05$. Dengan syarat : Jika P-value $\geq \alpha$, maka homogen dan Jika P-value $<\alpha$, maka tidak homogen.

\section{Deskripsi Data}

Deskrisi data hasil penelitian dimaksudkan untuk memberikan gambaran umum mengenai penyebaran / distribusi data, baik berupa ukuran gejala sentral, ukuran letak maupun distribusi frekuensi. Data yang sisajikan adalah data mentah dengan metode statistic deskriptif menggunakan program SPSS versi 16,0 yaitu simpangan baku, modus, median, mean, distribusi frekuensi, kuortosis, skewness serta grafik histogram. Data diperoleh menggunakan tiga instrument dari 75 responden, telah dinyatakan valid dan variabel pada uji coba prapenelitian.

Berdasarkan banyaknya variabel dan merujuk kepada masalah penelitian yang ada maka deskripsi data disajikan menjadi tiga bagian yakni (1) Metode belajar, (2) kepedulian orang tua, (3) prestasi belajar matematika. Hasil perhitungan deskriptif masing-masing variabel secara lengkap dapat dilihat pada lampiran. Sedangkan uraian singkat hasil perhitungan statistik deskriptif disajikan dalam tabel gabungan berikut : 
Tabel 1 Deskripsi Data Penelitian

Statistics

\begin{tabular}{|c|c|c|c|c|}
\hline & & $\begin{array}{c}\text { Motivasi Belajar } \\
\text { (X1) }\end{array}$ & $\begin{array}{c}\text { Kepedulian } \\
\text { Orang Tua (X2) }\end{array}$ & $\begin{array}{l}\text { Prestasi Belajar } \\
\text { Matematika (Y) }\end{array}$ \\
\hline \multirow[t]{2}{*}{$\mathrm{N}$} & Valid & 75 & 75 & 75 \\
\hline & Missing & 0 & 0 & 0 \\
\hline \multicolumn{2}{|c|}{ Mean } & 97.20 & 89.27 & 14.65 \\
\hline \multicolumn{2}{|c|}{ Median } & 98.00 & 89.00 & 15.00 \\
\hline \multicolumn{2}{|c|}{ Std. Deviation } & 7.476 & 6.481 & 5.419 \\
\hline \multicolumn{2}{|c|}{ Skewness } & -.598 & -.179 & .192 \\
\hline \multicolumn{2}{|c|}{ Std. Error of Skewness } & .277 & .277 & .277 \\
\hline \multicolumn{2}{|c|}{ Kurtosis } & .220 & -.224 & -.939 \\
\hline \multicolumn{2}{|c|}{ Std. Error of Kurtosis } & .548 & .548 & .548 \\
\hline \multicolumn{2}{|c|}{ Range } & 34 & 30 & 21 \\
\hline \multicolumn{2}{|c|}{ Minimum } & 77 & 73 & 4 \\
\hline \multicolumn{2}{|c|}{ Maksimum } & 111 & 103 & 25 \\
\hline
\end{tabular}

\section{Data Motivasi Belajar $\left(X_{1}\right)$}

Data motivasi belajar diperoleh dari istrument berupa angket yang terdiri atas 30 butir soal. Tiap item diberi skor dari satu sampai dengan lima menurut skala Likert. Berdsarkan tabel diatas diketahui bahwa skor maksimal 111 dan minimal 77. Berada pada angka rerata 97,20 standar deviasi 7,476 berarti 7,7\% dari skor rerata. Ini menunjukan bahwa disparitas motivasi belajar relatif rendah. Dapat disimpulkan bahwa motivasi belajar bersifat homogen.

Dari tabel 4.1 dapat dilihat bahwa median 98 lebih tinggi dari rerata skor 97,20 ini mengindikasi bahwa rata-rata responden yang berada ditingkat atas lebih banyak dibandingkan mereka yang berada ditingkat bawah. Berikut histogram yang memberikan gambaran mengenai distribusi skor motivasi belajar.



Gambar Grafik 2 Histogram Motivasi Belajar $\left(X_{1}\right)$ 
Berdasarkan grafik diatas disimpulkan bahwa tingkat sebaran data motivasi belajar relatif normal karena sebarannya berada pada kurva normal. Sedangkan data yang berada diluar kurva normal relatif sedikit.

\section{Data Kepedulian Orang Tua $\left(X_{2}\right)$}

Data kepedulian orang tua diperoleh dari instrument berupa angket yang terdiri atas 30 butir soal. Tiap item diberi skor dari satu sampai dengan lima menurut skala Likert. Berdasarkan tabel diatas diketahui bahwa skor maksimal 103 dan minimal 73. Berada pada angka rerata 89,27 standar deviasi 64,81 berarti 7,3\% dari skor rerata. Ini menunjukan bahwa disparitas kepedulian orang tua relatif rendah. Dapat disimpulkan bahwa kepedulian orang tua bersifat homogen. Berikut histogram yang memberikan gambaran mengenai distribusi skor kepedulian orang tua

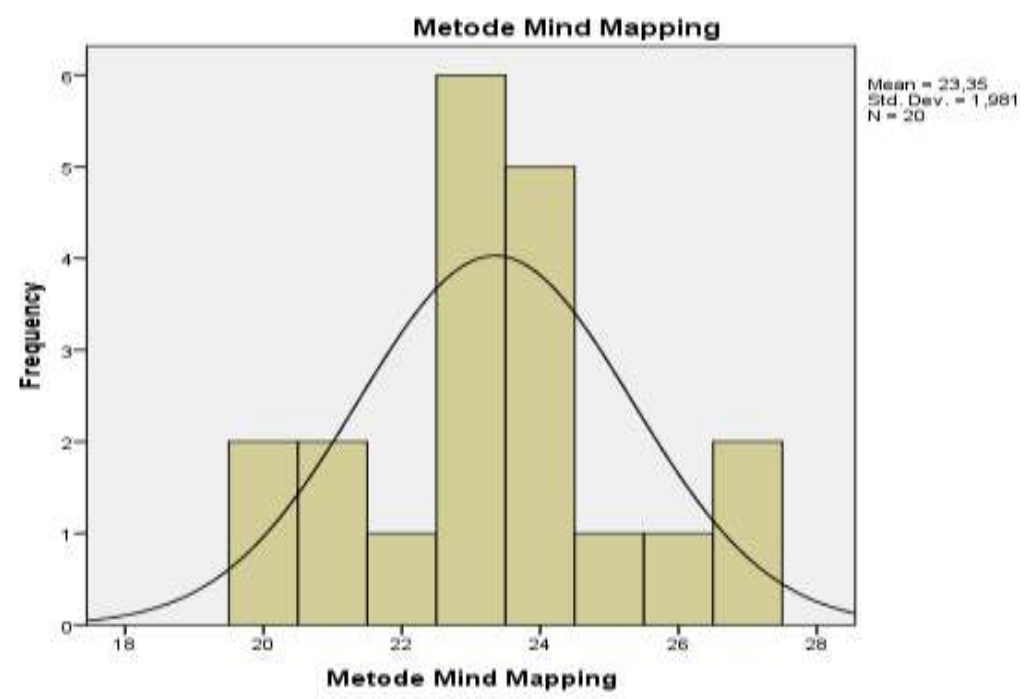

Gambar Grafik 3 Histogram Kepedulian Orang Tua $\left(X_{2}\right)$

Berdasarkan grafik diatas disimpulkan bahwa tingkat sebaran data kepedulian orang tua relatif normal karena sebarannya berada pada kurva normal. Sedangkan data yang berada diluar kurva normal relatif sedikit.

\section{Data Prestasi Belajar Matematika (Y)}

Data prestasi belajar matematika diperoleh dari instrument berupa soal tes pilihan ganda yang terdiri atas 30 butir soal. Tiap item diberi skor untuk jawaban benar satu dan nol untuk jawaban salah. Berdasarkan tabel diatas diketahui bahwa skor maksimal 25 dan minimal 4. Berada pada tingkat relata 14.65 standar deviasi 5.419 berarti $37.98 \%$ dari skor relata. Ini menunjukan bahwa disparitas prestasi belajar matematika relative rendah. Dapat disimpulkan bahwa prestasi belajar matematika bersifat homogen. Berikut histogram yang memberikan gambaran mengenai distribusi skor prestasi belajar matematika : 


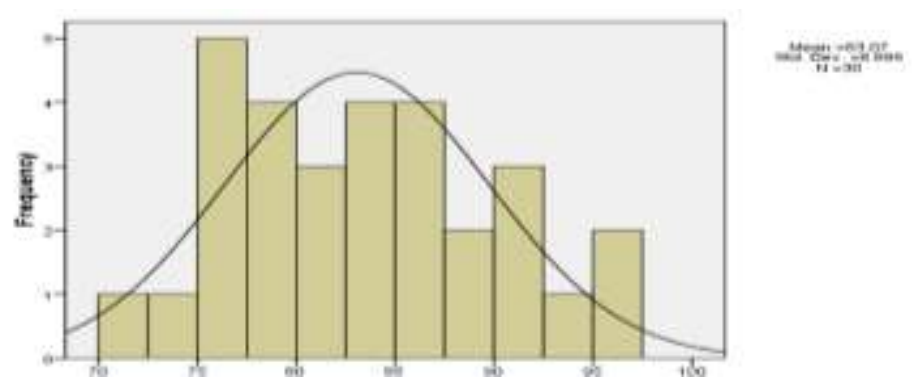

Gambar Grafik 4 Histogram Prestasi belajar Matematika (Y)

Berdasarkan grafik diatas disimpulkan bahwa tingkat sebaran data prestasi belajar matematika relative normal karena sebarannnya berada pada kurva normal. Sedangkan data yang berada diluar kurva normal relative sedikit.

\section{Pengujian Persyaratan Analisis}

Sebelum diadakan pengujian hipotesis, terlebih dahulu dilakukan pengujian persyaratan analisis menggunakan statistik inferensial melalui teknik korelasi sederhana dan regresi ganda. Persyaratan yang harus dipenuhi :

1. Data bersumber pada sampel berupa pasangan variabel $\mathrm{X}$ dan $\mathrm{Y}$ harus diambil secara acak dan memenuhi sampel minimum.

2. Untuk setiap kelompok harga variabel $X$ dan $Y$ harus independent berdistribusi normal.

Hubungan pasangan data $\mathrm{X}$ dan $\mathrm{Y}$ harus linear.

Untuk memenuhi persyaratan tersebut telah dilakukan pengujian analisis yaitu meliputi pengujian normalitas dan linearitas data dengan hasil tersaji sebagai berikut :

\section{Uji Normalitas}

Pengujian noramalitas masing-masing variabel dilakukan dengan maksud untuk mengetahui apakah sebaran data dari setiap variabel menyimpang dari ciri-ciri data berdistribusi normal. Pengujian dilakukan pada pasangan data $Y$ atas $X_{1}$ dan $Y$ atas $X_{2}$. Pengujian normalitas dilakukan terhadap variabel $\mathrm{Y}, X_{1}$ dan $X_{2}$ dengan rumusan hipotesis statistic sebagai berikut :

Ho : Data sampel berdistribusi normal $H_{1}$ : Data sampel tidak berdistribusi normal Perhitungan dilakukan menggunakan program aplikasi SPSS versi 16,0 dengan kriteria normalitas data adalah jika $P$ value (sig) $>0,05$ maka Ho diterima dan sebaliknya $H_{1}$ ditolak, yang berarti data berdistribusi normal. Dengan menggunakan metode Kolmogorov-Smirnov diperoleh hasil perhitungan seperti pada tabel berikut : 
Tabel. 2 Uji Normalitas Data Penelitian

\begin{tabular}{llrrr}
\hline & & $\begin{array}{c}\text { Motivasi Belajar } \\
(\mathrm{X} 1)\end{array}$ & $\begin{array}{c}\text { Kepedulian } \\
\text { Orang Tua (X2) }\end{array}$ & $\begin{array}{r}\text { Prestasi Belajar } \\
\text { Matematika (Y) }\end{array}$ \\
\hline $\mathrm{N}$ & & 75 & 75 & 75 \\
Normal Parameters* & Mean & 97.20 & 89.27 & 14.65 \\
& Std. Deviation & 7.476 & 6.481 & 5.419 \\
Most Extreme Differences & Absolute & 130 & .042 & .128 \\
& Positive & .066 & .042 & .128 \\
& Negative & -.130 & -.042 & -.078 \\
Kolmogorov-Smirmov Z & & 1.122 & .362 & 1.107 \\
Asymp. Sig (2-tailed) & & .161 & .999 & .172 \\
\hline a. test distribution is Normal & & & & \\
\hline
\end{tabular}

Dari hasil perhitungan dengan SPSS diatas menunjukan bahwa nilai uji statistik variabel motivasi belajar $\left(X_{1}\right)$, kepedulian orang tua $\left(X_{2}\right)$, dan prestasi belajar matematika $(\mathrm{Y})$ berturut-turut sebesar $0.161>0.05,0.999>$ 0.05 dan $0.172>0.05$ berarti Ho diterima $H_{1}$ ditolak, sehingga dapat disimpulkan bahwa data berdistribusi normal.

\section{Uji Multikolinearitas}

Pada pengujian Tes ini akan dilakukan dengan uji multikolinieritas dengan melihat nilai faktor inflasi (VIF) dalam model regresi dan membandingkan koefisien determinasi individu $\left(R^{2}\right)$. Kriteria Multikolinearitas adalah jika nilai tolerance $>0.10(10 \%)$ dan nilai Variance Inflation Factor (VIF) $<10$ maka data tidak mengalami Multikolinearitas dan sebaliknya. Dengan perhitungan menggunakan SPSS diperoleh hasil sebagai berikut :

Tabel.3 Hasil Uji Multikolinearitas

\begin{tabular}{|c|c|c|c|c|c|c|c|c|c|c|c|}
\hline \multirow{2}{*}{\multicolumn{2}{|c|}{ Model }} & \multicolumn{2}{|c|}{$\begin{array}{l}\text { Unstandardized } \\
\text { Coefficients }\end{array}$} & $\begin{array}{l}\text { Standar } \\
\text { dized } \\
\text { Coeffici } \\
\text { ents }\end{array}$ & \multirow[b]{2}{*}{$\mathrm{t}$} & \multirow[b]{2}{*}{ Sig. } & \multirow{2}{*}{$\begin{array}{l}\text { zero- } \\
\text { order }\end{array}$} & \multicolumn{2}{|c|}{ reelations } & \multicolumn{2}{|c|}{$\begin{array}{l}\text { Collinearity } \\
\text { Statistics }\end{array}$} \\
\hline & & B & $\begin{array}{l}\text { Std. } \\
\text { Error }\end{array}$ & Beta & & & & Partial & Part & Tolerance & VIF \\
\hline \multirow[t]{4}{*}{1} & (Constant) & -46.918 & 5.216 & & -8.995 & .000 & & & & & \\
\hline & Motivasi Belajar $X_{1}$ & .612 & .049 & .845 & 12.524 & .000 & .857 & .828 & .761 & .811 & 1.233 \\
\hline & Kepedulian & & & & & & & & & & \\
\hline & Orang Tua $\mathrm{X}_{2}$ & .123 & .056 & .028 & .410 & .683 & .395 & .048 & .025 & .811 & 1.233 \\
\hline
\end{tabular}

Dari tabel diatas terlihat kedua variabel bebas yang digunakan memiliki nilai tolerance lebih besar dari 0,10 yaitu $0,811>0,10$ dan nilai VIF $<10$ yaitu $1,233<10$ maka dapat disimpulkan data tidak mengalami multikolinearitas.

\section{Uji Heteroskedastisitas}

Uji Heteroskedastisitas akan dilihat pada gambar scatterplot yang menunjukan penyebran titik-titik. Kriteria pengujian adalah terjadi Heteroskedastisitas apabila gambar scatterplot menunjukan pola tertentu. Dari grafik scatterplot di atas menunjukkan bahwa titik-titik menyebar secara acak dan tidak membentuk pola-pola tertentu yang jelas, serta menyebar diatas maupun dibawah angka nol pada sumbu Y. 


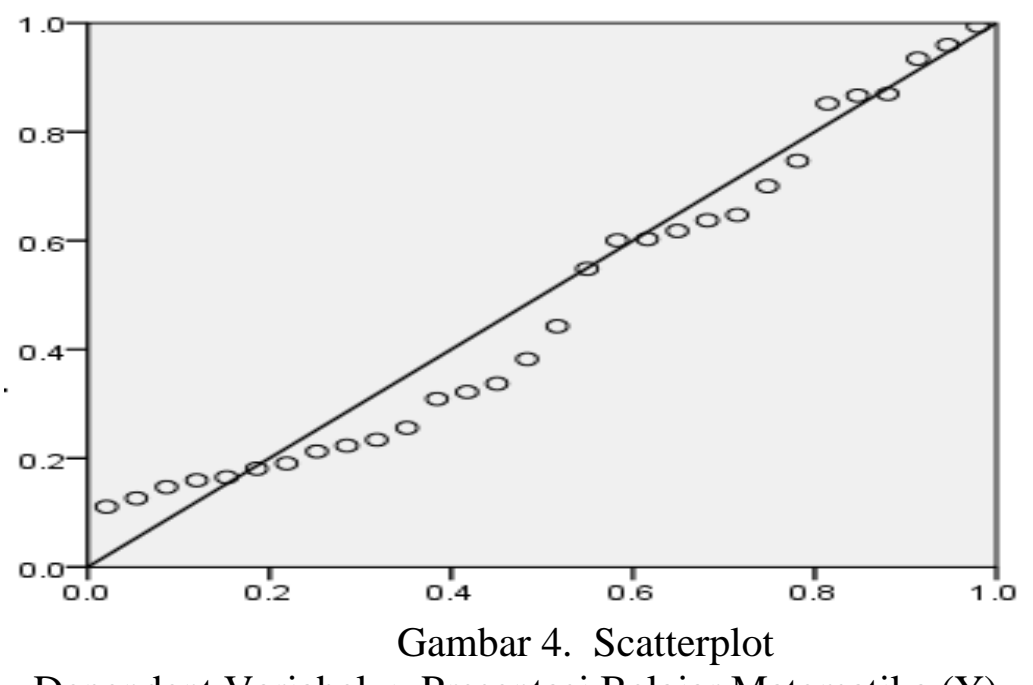

Dependent Variabel : Presentasi Belajar Matematika (Y)

Hal ini menunjukan bahwa tidak terjadi heteroskedastisitas pada model regresi tersebut, sehingga dapat dipakai untuk memprediksi variabel prestasi belajar Uji Normalitas Galat

Menggunakan perhitungan menggunakan SPSS versi 16.0 diperoleh hasil sebagai matematika berdasarkan motivasi belajar dan berikut : kepedulian orang tua.

Tabel .4 Hasil Pengujian Normalitas Galat

\begin{tabular}{llr}
\hline & & $\begin{array}{r}\text { Unstandardized } \\
\text { Residual }\end{array}$ \\
\hline $\mathrm{N}$ & Mean & 75 \\
Normal Parameters* & Std. Deviation & .0000000 \\
& Absolute & 2.79223392 \\
Most Extreme Differences & Positive & 110 \\
& Negative & .088 \\
& & -210 \\
Kolmogorov-Smirmov Z & & 361 \\
Asymp. Sig. (2-tailed) & & 325 \\
\hline
\end{tabular}

a. Test distribution is Normal

Kriteria : Data dikatakan normal apabila sig. > $0.05^{4}$ dari tabel diatas diketahui sig. $0.326>$ $0.05^{4}$ jadi dapat disimpulkan data tersebut normal.

\section{Uji Linearitas}

Pengujian Linearitas dalam penelitian ini menggunakan hipotesis sebagai berikut :

Ho : Garis regresi berhubungan antara variabel $\mathrm{X}$ dan variabel $\mathrm{Y}$ linear

$H_{1}$ : Garis regresi berhubungan antara variabel $\mathrm{X}$ dan variabel $\mathrm{Y}$ tidak linear.
Perhitungan dengan menggunakan program SPPS versi 16,0 kriteria dari normalitas data adalah jika sig. > 0.05 maka Ho diterima dan sebaliknya $H_{1}$ ditolak. Ini berarti bahwa garis regresi bersifat linear.

a. Linearitas garis regresi pengaruh variabel motivasi belajar $\left(X_{1}\right)$ terhadap prestasi belajar matematika (Y).

Hasil perhitungan pengujian linearitas garis regresi pengarus variabel bebas motivasi belajar terhadap variabel terikat prestasi belajar matematika dapat dilihat dalam tabel berikut : 
Tabel .5 Hasil Pengujian Linearitas Garis Regresi Pengaruh Motivasi Belajar $\left(X_{1}\right)$ Terhadap Prestasi Belajar Matematika (Y)

\begin{tabular}{|c|c|c|c|c|c|c|c|}
\hline \multicolumn{8}{|c|}{ ANOVA Tabel } \\
\hline & & & \multicolumn{2}{|l|}{ Sum of } & \multicolumn{3}{|l|}{ Mean } \\
\hline & & & Squares & $\mathrm{df}$ & Squares & $\mathrm{F}$ & Sig. \\
\hline Prestasi Belajar & Between & (Comoned) & 1777.345 & 26 & 58.359 & 8.293 & .000 \\
\hline Matematika $(\mathrm{Y})^{*}$ & Groups & Linearity & & & & & \\
\hline \multirow[t]{5}{*}{ Motivasi Belajar $\left(\mathrm{X}_{1}\right)$} & & & 1594.693 & 1 & 1594.693 & 193.471 & .000 \\
\hline & & Deviation from & 182.652 & 25 & 7.306 & & .620 \\
\hline & & Linearity & & & & & \\
\hline & Withim G & & 395.642 & 48 & 8.243 & .889 & \\
\hline & Total & & 2172.987 & 74 & & & \\
\hline
\end{tabular}

Pada tabel terlihat bahwa nilai sig lebih besar dari 0.05 sehingga Ho diterima dan $H_{1}$ ditolak. Berarti dapat dikatakan bahwa garis regresi pengaruh hubungan motivasi belajar terhadap prestasi belajar matematika bersifat linear.

b. Linearitas garis regresi pengaruh variabel kepedulian orang tua $\left(X_{2}\right)$ terhadap variabel prestasi belajar matematika (Y)

Hasil perhitungan pengujian linearitas garis regresi pengaruh variabel bebas motivasi belajar terhadap variabel terikat prestasi belajar matematika dapat dilihat dalam tabel berikut :

Tabel .6 Hasil Pengujian Linearitas Garis Regresi Pengaruh Kepedulian Orang Tua $\left(X_{2}\right)$ Terhadap Prestasi Belajar Matematika (Y)

\begin{tabular}{|c|c|c|c|c|c|c|c|}
\hline \multicolumn{8}{|c|}{ ANOVA Tabel } \\
\hline & & & \multirow{2}{*}{$\begin{array}{l}\text { Sum of } \\
\text { Squares }\end{array}$} & \multicolumn{3}{|c|}{ Mean } & \multirow[b]{2}{*}{ Sig. } \\
\hline & & & & $\mathrm{df}$ & Squares & $\mathrm{F}$ & \\
\hline Prestasi Belajar & Between & (Comoned) & 902.337 & 25 & 36.053 & 1.392 & .159 \\
\hline Matematika $(\mathrm{Y})^{*}$ & Groups & Linearity & & & & & \\
\hline \multirow{5}{*}{$\begin{array}{l}\text { Kepedulian Orang Tua } \\
\left(X_{2}\right)\end{array}$} & & & 339.243 & 1 & 339.243 & 13.082 & .001 \\
\hline & & $\begin{array}{l}\text { Deviation } \\
\text { from }\end{array}$ & 563.094 & 24 & 23.462 & 905 & .595 \\
\hline & & Linearity & & & & & \\
\hline & \multicolumn{2}{|c|}{ Withim Groups } & 1270.650 & 49 & 25.932 & & \\
\hline & \multicolumn{2}{|l|}{ Total } & 2172.987 & 74 & & & \\
\hline
\end{tabular}

Pada tabel terlihat bahwa nilai sig lebih besar dari 0,05 sehingga Ho diterima dan $H_{1}$ ditolak. Berarti dapat dikatakan bahwa garis regresi pengaruh motivasi belajar terhadap prestasi belajar matematika bersifat linear.

\section{Pengujian Hipotesis dan Pembahasan}

Pengujian hipotesis dilakukan seperti ketentuan pada Bab III. Hasil perhitungan dan pengujian dapat dilihat secara berurutan pada tabel berikut : 
Tabel 7 Hasil Perhitungan Pengaruh Motivasi Belajar $\left(X_{1}\right)$ dan Kepedulian Orang Tua $\left(X_{2}\right)$ Terhadap Prestasi Belajar Matematika (Y)

Model Summary

\begin{tabular}{|c|c|c|c|c|}
\hline$\partial d$ & $\mathrm{R}$ & R Square & $\begin{array}{l}\text { Adjusted R } \\
\text { Square }\end{array}$ & $\begin{array}{l}\text { Std. Error of the } \\
\text { Estimate }\end{array}$ \\
\hline & $.857^{a}$ & .734 & .727 & 2.831 \\
\hline
\end{tabular}

Tabel .8 Rekapitulasi Hasil Perhitungan Pengujian Signifikansi Koefisien Regresi Pengaruh Motivasi Belajar $\left(X_{1}\right)$ dan Kepedulian Orang Tua $\left(X_{2}\right)$ Terhadap Prestasi Belajar Matematika (Y)

ANOVA $^{\mathrm{b}}$

\begin{tabular}{llccccc}
\hline \multirow{2}{*}{ Model } & & Sum of & & Mean & & \\
\hline 1 & Regression & 1596.040 & 2 & 798.020 & 99.589 & $.000^{\text {a }}$ \\
& Residual & 576.946 & 72 & 8.013 & & \\
& & & & & & \\
& Total & 2172.987 & 74 & & & \\
\hline
\end{tabular}
a. Predictors : (Constant), Kepedulian Orang Tua $\left(X_{2}\right)$, Motivasi Belajar $\left(X_{1}\right)$
b. Dependen Variable : Prestasi Belajar Matematika $(\mathrm{Y})$

Tabel .9 Rekapitulasi Hasil Perhitungan Persamaan Garis Regresi Pengaruh Motivasi Belajar $\left(X_{1}\right)$ dan Kepedulian Orang Tua $\left(X_{2}\right)$ Terhadap Prestasi Belajar Matematika (Y)

\begin{tabular}{|c|c|c|c|c|c|c|}
\hline \multicolumn{7}{|c|}{ Coefficients $^{\mathrm{a}}$} \\
\hline & & & $\begin{array}{l}\text { andardized } \\
\text { efficients }\end{array}$ & & & \\
\hline \multicolumn{2}{|c|}{ Model } & B & Std. Error & Beta & $\mathrm{T}$ & Sig. \\
\hline \multirow[t]{3}{*}{1} & (Constant) & -46.918 & 5.216 & & -8.995 & .000 \\
\hline & Motivasi Belajar $\left(X_{1}\right)$ & .612 & .049 & .845 & 12.524 & .000 \\
\hline & Kepedulian Orang Tua $\left(\mathrm{X}_{2}\right)$ & .023 & .056 & .028 & .410 & .683 \\
\hline
\end{tabular}

a. Dependent Variable : Prestasi Belajar Matematika (Y)

Berdasarkan data diatas dapat disimpulkan :

1. Pengaruh motivasi belajar dan kepedulian orang tua terhadap prestasi belajar matematika

Pengujian Hipotesis 1 :

Ho : $\beta_{1}=\beta_{2}=0$

$\mathrm{H}_{1}: \beta_{1} \neq \beta_{2} \neq 0$

Artinya :

$H_{0}$ : Tidak terdapat pengaruh yang signifikan motifasi belajar dan kepedulian orang tua secara bersama-sama terhadap prestasi belajar matematika.

$H_{1}$ : Terdapat pengaruh yang signifikan motivasi belajar dan kepedulian orang

tua secara bersama-sama terhadap prestasi belajar matematika.

Berdasarkan tabel 4.5 terlihat bahwa koefisien korelasi ganda pengaruh variabel bebas motivasi belajar $\left(X_{1}\right)$ dan kepedulian orang tua $\left(X_{2}\right)$ secara bersama-sama terhadap prestasi belajar matematika $(Y)$ 
adalah sebesar 0,857. Sedangkan koefisien determinasi (R Square) sebesar 73,4\% (mayoritas), sisanya 26,6\% disebabkan oleh faktor lain.

Untuk pengujian hipotesis melalui analisis regresi diperoleh hasil perhitungan seperti dalam tabel 4.6 dan 4.7 berdasarkan tabel 4.7 diperoleh persamaan garis regresi yang mempresentasikan pengaruh variabel $\left(X_{1}\right)$ dan $\left(X_{2}\right)$ terhadap $(\mathrm{Y})$ yaitu $\mathrm{Y}=$ $46,918+0,612 X_{1}+0,023 X_{2}$ sementara untuk menguju signifikasi garis regresi tersebut adalah dengan memperhatikan hasil perhitungan yang ada pada tabel 4.6 menurut ketentuan yang ada, kriteria signifikasi regresi tersebut adalah jika nilai sig $<0,05$ maka Ho ditolak dan $H_{1}$ diterima atau jika $F_{\text {hitung }}>F_{\text {tabel }}$ maka Ho ditolak dan $H_{1}$ diterima yang berarti koefisien regresi signifikan.

Dari tabel 4.6 diketahui bahwa nilai sig $=0.000$ dan $F_{\text {hitung }}=99,589$ sedangkan $F_{\text {tabel }}$ dengan sig 0,05 derajat kebebasan $(\mathrm{k})=2$ dan derajat penyebut $(\mathrm{n}-\mathrm{k}-1)=72$ dengan $\mathrm{n}=$ banyaknya responden $=75, \mathrm{k}=$ banyaknya variabel bebas diperoleh nilai 3,124. Dengan demikian Ho ditolak dan $H_{1}$ diterima sehingga dapat disimpulkan bahwa terdapat pengaruh yang signifikan motivasi belajar dan kepedulian orang tua secara bersama-sama terhadap prestasi belajar matematika.

\section{Pengaruh motivasi belajar terhadap prestasi belajar matematika}

Pengujian Hipotesis 2 :

Ho : $\beta_{1}=0$

$\mathrm{H}_{1}: \beta_{1} \neq 0$

Artinya :

$H_{0} \quad$ : Tidak terdapat pengaruh yang signifikan motifasi belajar terhadap prestasi belajar matematika.

$H_{1}$ : Terdapat pengaruh yang signifikan motivasi belajar terhadap prestasi belajar matematika.

Berdasarkan tabel 4.7 terlihat bahwa sig = 0,000 dan $T_{\text {hitung }}=12,524$ sedangkan $T_{\text {tabel }}$ untuk sig 0,05 dengan derajat kepercayaan $(\mathrm{df}=\mathrm{n}-2)=73$ dengan $\mathrm{n}=$ banyaknya responden $=75$ adalah sebesar 1,993. Kriteria signifikasi regresi adalah jika $T_{\text {hitung }}>T_{\text {tabel }}$ maka Ho ditolak dan $H_{1}$ diterima atau jika sig < 0,05 maka Ho ditolak dan sebaliknya $H_{1}$ diterima. Dengan memperhatikan kriteria tersebut maka Ho ditolak dan $H_{1}$ diterima sehingga dapat disimpulkan bahwa terdapat pengaruh yang signifikan motivasi belajar terhadap prestasi belajar matematika.

\section{Pengaruh kepedulian orang tua} terhadap prestasi belajar matematika Pengujian Hipotesis 3 :

Ho : $\beta_{2}=0$

$\mathrm{H}_{1}: \beta_{2} \neq 0$

Artinya :

$H_{0} \quad$ : Tidak terdapat pengaruh yang signifikan kepedulian orang tua terhadap prestasi belajar matematika.

$H_{1}$ : Terdapat pengaruh yang signifikan kepedulian orang tua terhadap prestasi belajar matematika.

Berdasarkan tabel 4.7 terlihat bahwa sig $=$ 0,683 dan $T_{\text {hitung }}=0,410$ sedangkan $T_{\text {tabel }}$ untuk sig 0,05 dengan derajat kepercayaan $(\mathrm{df}=\mathrm{n}-2)=73$ dengan $\mathrm{n}$ banyaknya responden $=75$ adalah sebesar 1,993. Kriteria signifikasi regresi adalah jika $T_{\text {hitung }}>T_{\text {tabel }}$ yaitu $0,410<1,993$ maka Ho ditolak dan $H_{1}$ diterima atau jika sig < 0,05 sedangkan sig 0,683>0,05 maka Ho ditolak dan sebaliknya $H_{1}$ diterima. Dengan memperhatikan kriteria tersebut maka Ho diterima dan $H_{1}$ ditolak sehingga dapat disimpulkan tidak terdapat pengaruh yang signifikan kepedulian orang tua terhadap prestasi belajar matematika.

Penelitian ini untuk mengetahui pengaruh motivasi belajar dan kepedulian orang tua secara bersama-sama terhadap prestasi belajar matematika. 
1. Pengaruh motivasi belajar dan kepedulian orang tua secara bersama-sama terhadap prestasi belajar matematika

Koefisien korelasi ganda pengaruh variabel bebas motivasi belajar $\left(X_{1}\right)$ dan kepedulian orang tua $\left(X_{2}\right)$ secara bersama-sama terhadap prestasi belajar matematika (Y) adalah sebesar 0,857 sedangkan koefisien determinasi ( $\mathrm{R}$ square) sebesar 73,4\% (mayoritas) sisanya $26,6 \%$ disebabkan oleh faktor lain. Perseamaan garis regresi yang mempresentasikan pengaruh variabel $X_{1}$ dan $X_{2}$ terhadap $Y$ yaitu $\mathrm{Y}=-46,918$ $+0,612 X_{1}+0,023 X_{2} \quad$ walaupun konstanta dari persamaan bernilai negatif tetapi untuk nilai minimal berturut-turut $X_{1}$ dan $X_{2}$ yaitu 77 dan 73 maka nilai $\mathrm{Y}$ tetap positif yaitu 1,885 koefisien $X_{1}$ dan $X_{2}$ menunjukan adanya pengaruh alternatif secara bersama-sama terhadap Y. Artinya bahwa setiap ada kenaikan nilai satu motivasi belajar maka akan terdapat kenaikan prestasi belajar matematika sebesar 0,612 dan nilai satu kepedulian orang tua maka akan terdapat kenaikan prestasi belajar matematika sebesar 0,023 .

\section{Pengaruh motivasi belajar terhadap prestasi belajar matematika}

Dari pengujian hipotesis diperoleh $T_{\text {hitung }}=12,524$ sedangkan $T_{\text {tabel }}$ untuk sig 0,05 dengan derajat kepercayaan $(\mathrm{df}=\mathrm{n}-2)=73$ dengan $\mathrm{n}$ $=$ banyaknya responden $=75$ adalah sebesar 1,993. Kriteria signifikasi regresi adalah jika $T_{\text {hitung }}>T_{\text {tabel }}$ maka Ho ditolak dan $H_{1}$ diterima atau jika sig $<0,05$ maka Ho ditolak dan sebaliknya $H_{1}$ diterima. Dengan memperhatikan kriteria tersebut maka Ho ditolak dan $H_{1}$ diterima sehingga dapat disimpulkan bahwa terdapat pengaruh yang signifikan motivasi belajar terhadap prestasi belajar matematika.

\section{Pengaruh kepedulian orang tua terhadap prestasi belajar matematika}

Dari pengujian terlihat bahwa sig $=$ 0,683 dan $T_{\text {hitung }}=0,410$ sedangkan $T_{\text {tabel }}$ untuk sig 0,05 dengan derajat kepercayaan $(\mathrm{df}=\mathrm{n}-2)=73$ dengan $\mathrm{n}$ $=$ banyaknya responden $=75$ adalah sebesar 1,993. Kriteria signifikasi regresi adalah jika $T_{\text {hitung }}>T_{\text {tabel }}$ yaitu $0,410<1,993$ maka Ho ditolak dan $H_{1}$ diterima atau jika sig $<0,05$ sedangkan sig 0,683 >0,05 maka Ho ditolak dan sebaliknya $H_{1}$ diterima. Dengan memperhatikan kriteria tersebut maka Ho diterima dan $H_{1}$ ditolak sehingga dapat disimpulkan bahwa tidak terdapat pengaruh yang signifikan kepedulian orang tua terhadap prestasi belajar matematika. Dari pengujian dengan SPSS 16 diatas didapat sig. Untuk kepedulian orang tua $0,142>0,05$ dan $F_{0}=3,943$ dengan demikian kesimpulannya adalah tidak terdapat pengaruh kepedulian orang tua yang signifikan terhadap prestasi belajar matematika. Fenomena ini menunjukan bahwa prestasi belajar matematika siswa tidak terpengaruh oleh kepedulian orang tuanya.

\section{SIMPULAN}

Berdasarkan dari hasil pengujian hipotesis penelitian dan analisis pengolahan data pada Bab IV, maka dapat disimpulkan sebagai berikut :

1. Terdapat pengaruh yang signifikan motivasi belajar dan kepedulian orang tua secara bersama-sama terhadap prestasi belajar matematika. Hal tersebut dibuktikan dengan nilai sig = 0,000 dan $F_{\text {hitung }}=99,589$ sedangkan $F_{\text {tabel }}$ denga sig 0,05 derajat kebebasan $(\mathrm{k})=2$ dan derajat penyebut $(\mathrm{n}-\mathrm{k}-1)=72$ dengan $n=$ banyaknya responden $=75$, $\mathrm{k}=$ banyaknya variabel bebas, diperoleh nilai 3,124 sehingga kriteria nilai sig $<0,05$ dan $F_{\text {hitung }}>F_{\text {tabel }}$ terpenuhi jika dapat disimpulkan koefisien regresi signifikan. 
2. Terdapat pengaruh yang signifikan motivasi belajar terhadap prestasi belajar matematika. Hal tersebut dibuktikan dengan nilai sig $=0,000$ dan $t_{\text {hitung }}=12,524$ sedangkan $t_{\text {tabel }}$ untuk sig 0,05 dengan derajat kepercayaan $(\mathrm{df}=\mathrm{n}-2)=73$ dengan $\mathrm{n}$ $=$ banyaknya respoden $=75$ adalah sebesar 1,993. Sehingga kriteria signifikansi regresi dipenuhi.

Terdapat pengaruh yang tidak signifikan kepedulian orang tua terhadap prestasi belajar matematika. Hal tersebut dibuktikan dengan sig $=$ 0,683 dan dan $t_{\text {hitung }}=0,410$ sedangkan $t_{\text {tabel }}$ untuk sig 0,05 dengan derajat kepercayaan $(\mathrm{df}=\mathrm{n}-2)=73$ dengan $\mathrm{n}=$ banyaknya responden $=75$ adalah sebesar 1,993. Kriteria signifikasi regresi adalah jika $t_{\text {hitung }}>$ $t_{\text {tabel }}$ yaitu $0,410<1,993$ maka Ho ditolak dan $H_{1}$ diterima atau jika sig < 0,05 sedangkan sig $0,683>0,05$ dengan demikian kesimpulannya adalah terdapat pengaruh kepedulian orang tua yang tidak signifikan terhadap prestasi belajar matematika.

\section{DAFTAR PUSTAKA}

Ali, Muhammad dan Muhammad Asrori. 2002. Psikologi Remaja (perkembangan peserta didik). Jakarta : Rineka Cipta.

Alwi, Hasan. Dkk. 2002. Kamus Besar Bahasa Indonesia. Jakarta : Balai Pustaka.

Arikuto, Suharsimi. 2002. Prosedur Penelitian. Jakarta : Reneka Cipta. 2010. Dasar-Dasar Evaluasi Pendidikan. Bumi Aksara. Jakarta.

Aunurrahman, M.Pd. 2010. Belajar dan Pembelajaran. Bandung : Alfabeta.

Bahruddin dan Esa Nur Wahyuni. 2010. Teori Belajar dan Pembelajaran. Jogyakarta : Ar-ruzz. Media.

Dali, Kartini Mutakdin. 1987. Pengaruh Hubungan Manusia di Kalangan Siswa Terhadap Kemandirian Belajar. Jakarta : Depdikbud.
Dhesiana. 2009. Kemandirian Dalam

Belajar. http : //dhesiana.

Wordpress.com/2009/01/16/.

Drost, SJ. 1993. Menjadi Pribadi Dewasa dan

Mandiri. Yogyakarta : Kaninsius.

Dimyati, Mujdiono. 2002. Belajar dan Pembelajaran. Jakarta : Rineka Cipta.

E. Mulyasa. 2005. Kurikulum yang Disempurnakan. Jakarta : PT. Rineka Cipta Karya.

Hamalik, Oemar. 2002. Psikologi Belajar dan Mengajar. cetakan ke III Bandung : Sinar Baru Algasindo.

Izan Tahar. (irsan@mail.ut.ac.id) dan Encang (encang@mail.ut.ac.id).2003. Jakarta : Universitas Terbuka, Diakses tanggal 28 Juli 2012.

Jaali. 2002. Pengukuran Dalam Bidang Pendidikan. Jakarta : Pascasarjana UNJ).

Mujdiono. 2002. Belajar dan Pembelajaran. Jakarta : Rineka Cipta.

Purwanto. M. Ngalim. 2008. Psikologi Pendidikan. Bandung : Remaja Karya CV.

Ruseffendi. 2006. Pendidikan Hasil Belajar Mengajar. Bandung : Remaja Rosdakarya.

Shochib, Moh. 2000. Pola Asuh Orang Tua. Jakarta : Rineka Cipta.

Sisdiknas. 2003. Undang-Undang Republik Indonesia Nomor 20 tahun 2003. Bandung : Fokus Media.

Sudjana. 2005. Metode Statistik. Bandung : Tarsito.

Supardi. 2012. Aplikasi Statistika Dalam Penelitian. Jakarta : Ufuk Press.

Susilo. Djoko. 2009. Sukses Dengan Gaya Belajar. Pinus. Yogyakarta.

Syah. Muhibbin. 2010. Psikologi Pendidikan Dengan Pendekatan Baru. Bandung : Remaja Rosdakarya

Tim Bahasa. 2003. Kamus Besar Bahasa Indonesia. Edisi ketiga. Jakarta : Balai Pustaka.

Tim Pengembang Ilmu Pendidikan. FIP-LIPI. 2009. Ilmu dan Aplikasi Pendidikan. Bandung : IMTIMA

Tim Penyusun 2010. Pedoman Penyusunan Tesis. Universitas Indraprasta PGRI Jakarta. 